\title{
The effect of the situational factor, store atmosphere, and sales promotion on hedonic shopping motivation and its implication on supermarket consumer impulsive buying in Manado city
}

\author{
Nova Ch. I. Mamuaya \\ Aditya Pandowo \\ Universitas Negeri Manado, Indonesia
}

\section{Keywords}

Situational Factor, Store Atmosphere, Sales Promotion, Hedonic Shopping Motivation, Impulsive Buying, Supermarket

\begin{abstract}
The purpose of this study was to determine and analyse 1) the effect of the situational factor, store atmosphere, and sales promotion on hedonic shopping motivation and 2) the impact of situational factor, store atmosphere, sales promotion, and hedonic shopping motivation on supermarket consumer impulsive buying in Manado City, partial or simultaneously. The method used in this research is the descriptive survey and explanatory survey method, with 250 consumers who shop in several supermarkets as the sample with convenience sampling technique; primary data were collected using questionnaire with Likert scale and SEM (structural equation modeling) analyse technique using Lisrel 8.80 program.

The result shows that situational factor did not significantly affect the hedonic shopping motivation while store atmosphere and sales promotion are positively related to it. Meanwhile, situational factor and sales promotion are significantly related to impulsive buying. In contrast, store atmosphere shows the opposite way to impulsive buying. Further, impulsive buying is also predicted by hedonic shopping motivation.

The increasing of customers' impulsive buying behaviour occurs concerning with shopping for social purposes and sales promotion. The first approach is obtained from marketing strategy and customer service strategy while the second approach is achieved through information strategy, communication, and frequency of sample providing program.
\end{abstract}

Corresponding author: Nova Ch. I. Mamuaya

Email addresses for the corresponding author: novachmamuaya@unima.ac.id

First submission received: $10^{\text {th }}$ January 2018

Revised submission received: $20^{\text {th }}$ July 2018

Accepted: $30^{\text {th }}$ August 2018

\section{Introduction}

Impulsive buying behaviour has attracted the interest of academic researchers because the result seemed to be a contradiction between what people plan to do with what they finally do (Gutierrez, 2004). Literature and consumer themselves admit that impulsive buying behaviour is wrong normatively, but with large buying volume in various product categories classified as impulsive buying (Rook, 1987 in Gutierrez, 2004). From the consumer side, impulsive buying behaviour brings negative implication such as excessive spending money, unnecessary purchases, uncertainties and risks regarding the function and product quality, and a sense of guilt. Therefore, impulsive buying is often considered irrational and risky. However, impulsive buying behaviour phenomenon is something that still happens in consumer buying behaviour and large-scale studies on this topic have been started since about sixty years ago until today (Gutierrez, 2004).

Impulsive buying covers $80 \%$ of all purchases (Kacen \& Lee, 2002), $62 \%$ of supermarket sales and $80 \%$ of all sales in certain product categories (Ahmad, 2011). According to Handi Irawan in Marketing magazine special edition in 2008, said there are 10 Indonesia Customer Character, one of which is the unplanned or impulsive character. Indonesian consumers' is a kind of consumers who are not accustomed to something. Although they do, they will decide at the last moment. One form of consumer behaviour that has no plan is the occurrence of impulsive buying. Based on Nielsen (2008), it turns out that $85 \%$ of modern retail shoppers tend to shop for something that was not planned. The preliminary survey 
conducted by the author in three large supermarkets in Manado City that most visited by consumers are Multimart Ranotana, Freshmart Bahu, and Golden Sam Ratulangi in August 2013 with 30 consumers as respondents showed that $18(60 \%)$ shop for products unplanned or impulsive. The preliminary survey was done by asking questions to customers after they finished shopping, "is that any items that you buy unplanned before?" Similarly, a survey in September 2014 and in August 2015 in same location and number of correspondents indicate that in September 2014 is 20 people $(70 \%)$ do impulsive buying and in August 2015 as many as 22 people $(73,3 \%)$. The survey results show that consumers' impulsive behaviour in supermarkets at Manado City tends to increase over the last three years.

Knowledge and understanding of consumer impulsive buying behaviour and its influencing factors become essential for modern retail companies in the preparation of the strategy in the face of modern retail business competition that getting tighter. Several studies about impulsive buying have been done, mostly in developed countries like the United States and European countries, as well as in some developing countries, including Indonesia. In the study, the researchers of marketing and consumer behaviour primarily focused on identifying factors that increase impulsive buying (Tinne, 2010). In Indonesia's own country, especially in Manado City, research on impulsive buying and the factors that influence is still very little.

Previous research proved that several determinants could predict impulsive buying perfectly. Demographic characteristics such as age (Wood, 1998); gender (Dittmar, Beattie and Friese, 1996); culture (Kasen and Lee, 2002) or affective factors such as emotional (Beatty and Ferrell, 1998) plays a vital role in predicting impulsive buying. Further, some impulsive buying also associated to hedonic pleasure such as pleasure, discover and experience new things, fantasy, social interaction, and emotional (Hausman, 2000) and the tendency to buy impulsively (Beatty and Ferrell, 1998).

Youn and Faber (2000) found that the store atmosphere increases the likelihood of impulsive behaviour; Iyer and Ahlawat (1987) found that consumers tend to be impulsive in the type of food stores. In connection with the situational factors, Beatty and Ferrell (1998) found that the availability of time and money influencing impulsive buying. Relating to the characteristics of the product, Babin, Darden and Griffin (1994) found that impulsive buying occur in the case of the hedonic product category.

However, several studies produce different findings on certain factors. The first side found that situational factors (availability of time and money) significantly influence the impulsive buying behaviour (Wu and Huan, 2010; Foroughi, Remove, and Sadeghi, 2012; and Srivastava and Kumar (2013). Some found that situational factors (availability of time and money) do not significantly influence the impulsive buying (Maymand and Ahmadinejad, 2011).

The contradiction also happened when some researchers found an effect of store atmosphere on impulsive buying (Crawford and Melewar, 2003; Park and Lennon, 2006; Soars, 2009; and Graa, DaniElkebir and Bensaid, 2014) while the other found against the first side. Tendai \& Crispen (2009) showed that the factors associated with the store atmosphere such as subscriber density, the fragrance in the store, the background music, and ventilation does not significantly influence impulsive buying.

Based on previous research, some sales promotion indicators can affect impulsive buying, for instance: product discount and cheaper price (Zhou and Wong, 2003); coupons, vouchers, promotions and advertising as well as low prices (Tendai and Crispen, 2009); free product and price discount (Karbasivar and Yarahmadi, 2011); and bonus packs (Xu and Huang, 2014). Nevertheless, another study by Nagadeepa, Tamil Selvi \& Pushpa (2015) showed that the three techniques, namely sales promotion coupons, packaging prices, and the contest do not affect impulsive buying.

Research conducted by Foroughi, Discard, Senik, and Sadeghi (2013) showed that situational factors (availability of time and money) affect the hedonic shopping motivations and situational factors influence the impulsive buying through hedonic shopping motivation; Babin and Attaway (2000) suggested that situational factors can generate positive and negative perceptions that will affect the hedonic shopping value. Store atmosphere can influence the creation of consumer hedonic value (Coley and Burgess, 2003); Ballantine, Jack, and Parsons (2010) finds that these elements can store atmosphere make the shopping experience more enjoyable that evoke emotions and create consumer hedonic value; Zhang, Sirion, and Combs (2011) found that the store atmosphere affect consumer hedonic value; and Donovan \& Rossiter in the Bohl (2012) states that the fun and excitement of a hedonic value which has a 
significant influence as mediator of store atmosphere and consumer behaviour, including impulsive buying behaviour (Bohl 2012: 5). Research conducted by Maymand and Ahmadinejad (2011) on the role of environmental stimulation caused store promotions to impulsive buying, where the research results indicate that promotional incentives in the form of sales promotion and advertising significantly influence hedonic shopping motivation.

Hausman (2000) found that consumers who shop to satisfy their hedonic will like to look for new experiences, seek variety and excitement turns significantly affect impulsive buying. Impulsive buying plays an important role in satisfying the hedonic desire related to hedonic consumption. This role supports the conceptual relationship between hedonic shopping motivations with impulsive buying (Rock, 1987; Piron, 1991; and Hausman, 2000). Research by Park and Lennon (2006) indicates that the value that hedonic encourage impulsive buying. Silvera, Lavack, and Kropp (2008) suggest that impulsive buying behavior is often done to satisfy the motif that is hedonic. Harmancioglu, Finney, and Joseph (2009) found that consumers' emotional values such as pleasure increase the tendency of impulsive buying behaviour. Consumers who are shopping for leisure expect higher hedonic value level. The desire of consumers to seek the hedonic value of shopping can generate their impulsive buying (Holbrook and Herdsman, 1982; Rook, 1987 in Hausman, 2000). However, research conducted by Rohman (2009) found that hedonic shopping does not affect impulsive buying.

The purpose of this study was to determine and analyse the effect of situational factors, store atmosphere, and sales promotion to both hedonic shopping motivation and impulsive buying behaviour partially and simultaneously. The article is organized started by analysis the theoretical framework and hypotheses are proposed. Next, we exposed the methodology and instrument used in the study and presented the statistical analyses made as well as the principal findings. And finally, we will offer the conclusions, limitations of this study, and directions for future research at the end of the paper.

\section{Literature review \\ Situational Factor}

Mowen \& Minor in Sumarwan (2011:326) argued that the consumer situation is temporary environmental factors that cause a condition where consumer behaviour appears at a time and a place. The situation of consumers consists of three factors: (1) the place and time in which the behaviour occurred, (2) an explanation of why the behaviour occurs, and (3) the effect on consumer behaviour. Consumer situations of short duration while other factors, such as personality and culture usually last long. All those factors are particular to a time and place that do not follow from knowledge of the stable attributes of the consumer and the stimulus and that influence current behaviour (Hawkins \& Mothersbaugh 2009).

According to Mihic \& Kursan (2010), situational factors are the external factors coming from the shopping environment when a buyer enters into contact with particular visual stimuli (product or promotion) that create the unplanned purchase. At that instant, the shopper may feel a sudden need to purchase a product that has attracted his/her attention. There are two situational factors which are essential for impulsive buying behaviour, namely: (1) Time available, is the amount of time the shopper feels she/he has available that day. The more time consumers have, the longer consumers will spend time surfing or browsing in shopping environments that will ultimately affect the impulsive buying behaviour, and (2) Money available, is the amount of budget or extra money the individual perceives she or he must spend on that day. The availability of money is a facilitator in the process of impulsive buying because it will increase the consumer buying power. If consumers do not have enough money, the consumer will avoid shopping environment itself (Beatty and Ferrell in Foroughi, Throw \& Sadeghi (2012); Srivastava \& Kumar (2013); and Muruganantham \& Ravi Shankar (2013)

Situational factors can encourage customers to decide emotionally rather than rational. As a result, the likelihood to behave utilitarian is increasing along with their perceptions. Therefore, we proposed:

H1: there is an influence of situational factor on consumer hedonic shopping motivation

Situational factors can enhance customers' willingness to spend more time in a shopping center. Combination of money and time availability will drive consumers to buy spontaneously (Beatty and 
Ferrel, 1998). Consequently, the possibility of expending is increasing along the resources they have. Therefore, we proposed:

\section{H2: There is an influence of situational factor on consumer impulsive buying}

\section{Store Atmosphere}

Store atmosphere is defined as buying environments to produce specific emotional effects to produce commercially significant actions (Arnould, Price \& Tierney in Bohl, 2012) including purchase probability (Kotler in Bohl, 2012). In other words, store atmosphere plays as a crucial role as stimuli leading to some cognitive effect within the individual which, in turn, leads to some behavioural response (Turley and Milliman in Bohl, 2012).

Mowen \& Minor in Sumarwan (2011) explained that the atmosphere (atmospherics) is a more general term than the spatial store, the atmosphere (atmospherics) relates to how managers can manipulate the design of buildings, interior space, spatial halls, texture rugs and walls, smells, colours, shapes, and sounds experienced by customers (all of them to achieve a specific effect). Even goods arrangement, exhibitions/performances types, and dolls can affect consumer perceptions on a per-store atmosphere. These elements are incorporated in the definition developed by Philip Kotler, who described the atmospherics in an effort to design buying environments to produce a special emotional impact to the buyer that possibly increase the buying.

Turley \& Milliman in Bohl (2012) classifies these stimuli in five categories: (1) External variables cover: storefront, entrance, windows display, building architecture, and parking lot; (2) General interior variables cover: lighting, sound, temperature, cleanliness, colour usage; (3) Layout and design covers: fixture, product grouping, traffic flow; (4) Point-of-purchase and decoration covers: product display, point-ofpurchase display, product location sign, price sign; (5) Human variables cover: customer crowding or destiny, employee characteristic, employee uniform. A pleasure and delight atmosphere in the store will make a consumer more enjoyable and gain positive experience. Customer's positive feeling can evoke their emotional decision regarding their shopping behaviour caused by irrational expression. If it happens, the creation of hedonic shopping motivation is only a matter of time. Therefore, we proposed:

\section{H3: there is an influence of store atmosphere on consumer hedonic shopping motivation}

The relationship between store atmosphere and impulsive buying is still debatable. A prior study shows the relation is unsustainable because the findings indicate contrast argument. Some researchers found an effect of store atmosphere on impulsive buying (Crawford and Melewar, 2003; Park and Lennon, 2006; Soars, 2009) while Tendai and Crispen (2009) proved in contrast way. Nevertheless, the type of food stores can stimulate consumers' impulsive buying behaviour. Therefore, we proposed:

\section{H4: There is an influence of store atmosphere on consumer impulsive buying}

Sales Promotion

According to Kotler \& Keller (2009), sales promotion is a core ingredient in the marketing campaign that consists of incentive tools collection, mostly short-term, designed to stimulate the purchase of a faster or larger on specific products or services by customers or trade. The nature of sales promotion is a short-term deal that valid for buyers, retailers, or wholesalers (Tjiptono \& Chandra, 2012: 367) to encourage the purchase or sales of a product or service (Kotler \& Armstrong, 2012).

Sales promotion is different from advertising based on the purpose of buying behavior. Whereas advertising offers reasons to buy a product or service, sales promotion offers reasons to buy now (Kotler \& Armstrong, 2012).

Kotler and Keller (2009) suggest that sellers use promotional incentives to attract new experimentalist, appreciate loyal customers, and increase the repurchase rate users rarely buy. Sales promotion often draws people who like to switch brands, which are mainly looking for a lower price, better value, or premiums. If some of them do not try the brand, promotions may generate market share in the long term. Promotions to encourage consumers to try new products and lead to more diverse retail formats, such as everyday low pricing and pricing promotions. 
Kotler \& Armstrong (2012) argues that sales promotion covers consumer promotion, trade promotion, and business promotion and sales power tools. The main consumer promotion tools covers: (1) Sample, offers a number of free products or services which are delivered from door to door, sent by mail, was taken at the shop, affixed to another product, or displayed in the ad deals; (2) Coupon, a certificate that makes its holder has the right to make a written savings towards certain product buying: delivered by mail, bundled into other products or affixed to the product, or inserted in the magazine and newspaper ads; (3) Cash refund offer (rebate), give a price reduction after the purchase rather than in a retail store: Consumers send a certain "buying proof" to producer who "returns" half of buying price by mail: (4) Packaging price (price reduction agreement); offering consumers save on product regular price, placed on label or packaging. Low packaging price is a single package sold at bargain prices (such as two for one item price). Bound packaging is two related products which are bound together (such as toothbrushes and toothpaste); (5) Premium (prize), The goods are offered at relatively low cost or free as an incentive to buy a product. Inpackaging premium is accompanying the product inside the packaging. Premium in free letters sent to consumers who submit buying proof such as the top of the box or the UPC code. Liquidation premiums are sold under the normal retail price to consumer who requests it; (6) Frequency program, a program that gives reward associated with the frequency and intensity of consumers into buying products or services; (7) Gifts (contest, lottery, games), Gifts offers the opportunity to win cash, trips, or goods as a result of buying something. The competition requires consumers to provide inputs to be studied by a panel of judges who will select the best entries. Lottery asks consumers to collect their names were drawn. The game displays a game to consumers every time the buy - bingo numbers, missing letters - that might help them win a prize; (8) Patronage award, the value in cash or in other forms that comparable to a certain patronage vendor or vendor group; (9) Free trial, inviting prospective buyers to try the product for free in the hope they will buy; (10) Product warranty, explicit or implicit promise by the seller that the product will perform as well, if not, the seller will fix it or refund the customer's money during a specific period; (11) Tied promotion, two or more brand or company partnered issuing coupons, refunds, and held a contest to increase the attractiveness; (12) Cross promotion, use one brand to advertise other brands that do not compete; (13) Point-of-purchase and display $(P-O-P)$, display and demonstration conducted at the point of purchase or sale.

As an external stimulation, store promotion plays a role to endorse incentives for customers. It will push consumers to buy in order to satisfy their feelings. Consumers' hedonic value reflects the emotional feeling. Therefore, we proposed:

\section{H5: there is an influence of sales promotion on consumer hedonic shopping motivation}

When sales promotion indicators such as coupons and vouchers along with promotion and advertising had been introduced to customers, the tendency of customers' buying spontaneous is increasing as a result. The same result also happened if a company offer a free product and price discount (Tendai and Crispen, 2009; Karbasivar and Yarahmadi, 2011). However, another study on sales promotion indicators showed that packaging prices and contest has no effect on impulsive buying. Surely, consumer who has been persuaded by a beneficial stimulation will enhance their will to buy immediately. Therefore, we proposed:

\section{H6: there is an influence of sales promotion on consumer impulsive buying}

Hedonic Shopping Motivation

According to Arnold and Reynold in Utami (2010: 47), consumer motivation to shopping can be classified as two types namely (1) Utilitarian Shopping Motivation that is the motivation of consumers to shop for really need or benefit from the products purchased; (2) Hedonic shopping motivation that is consumer motivation to buy because shopping is a pleasure that does not pay attention to the benefits of the product purchased. Babin in Utami (2010) said that the hedonic aspects related to consumer emotional so when shopping consumers feel something like: adventure, gratification, role, value, social, ideas, and social shopping to measure one's motivation to go shopping.

Hedonic is defined as one type of needs based on the direction of motivation that subjective and experiential, which means that consumers must rely on a product to find their need for excitement, 
confidence, delusion or emotional responses. (Solomon in Utami, 2010). Meanwhile, hedonic shopping value is defined as entertainment and emotional value that customers perceived that arise through the shopping experience (Babin, Darden and Griffin, 1994). Based on some understanding above, it can be concluded that the characteristics of hedonic shopping value is a pleasure, emotional value and entertainment potential shopping.

According to Arnold \& Reynold in Utami (2010) said that there are six hedonic shopping motivation factors: (1) Adventure shopping, Most consumers shop because there is something that can excite spending from consumers themselves, feel that shopping is an experience and with shopping consumer seemed to have their own world; (2) Social shopping, Most consumers assume that enjoyment in shopping will be created when consumers spend time together with family or friends. Some consumers feel that shopping is an activity for socializing with others or with employees who work in the stores. Consumers also believe that, by shopping together with family or friends, the consumer will get a lot of information about the product to be purchased; (3) Gratification shopping, shopping is one alternative to reduce stress, overcome lousy atmospheric heart, and shopping is a means of forgetting the problems being faced; (4) Idea shopping, Consumers shop for a new fashion following the trend and to see a product or something new. Usually consumers go shopping for something new from advertising offered through the mass media; (5) Role shopping, Many consumers prefer to shop for others than for himself so that consumers feel that shopping for others is a fun thing to do; (6) Value shopping, consumers assume that shopping is a game that at the time of the bargain price, or when the consumer looking for a department store that offers a discount, closeout, or shopping at a cheap price.

Consumers who want to satisfy their hedonic behavior will turn to be the impulsive buyer because they look for new experience, seek variety, and excitement Hausman (2000). In other words, their desire to seek hedonic value of shopping will generate impulsive buying. If consumer faces a hedonic product category, the impulsive buying behavior emerges (Babin, Darden, and Griffin, 1994). Therefore, we proposed:

H7: there is an influence of hedonic shopping motivation on consumer impulsive buying

Impulsive Buying

Impulsive buying is defined as a desire or impulse sudden and powerful to buy something (Rook in Utami, 2010) and the propensity to purchase products quickly (Rock and Gardner, 1993) without a goal prior to purchase, whether to buy a specific product category or to meet particular needs (Beatty and Ferrell, 1998). Impulsive buying behaviour is hedonically complex and will stimulate emotional conflict by ignoring the consideration of the consequences (Rook in Utami, 2010).

Jones et al. in Dhaundiyal \& Coughlan (2009) identified three characteristics that distinguish an impulsive buying with other buying behaviours, namely: unintentional, unreflective and immediate. Being unintentional refers to a situation where the consumer is not actively looking for the product but buys it in the course of shopping. The second trait, unreflective, implies the consumer's lack of evaluation regarding the product and unwillingness to think about the long-term consequences with only short-term indulgence in mind. The third trait relates to the immediacy of purchase, i.e. the period between the stimulus, i.e. seeing the product and consequently buying the product is very little. An impulse purchase is a fast activity, i.e. consumer tends to buy it almost immediately after seeing it without applying much thought.

H8: there is an influence of situational factors, store atmosphere, and sales promotion on hedonic shopping motivation

H9: there is the influence of situational factors, store atmosphere, sales promotion, and hedonic shopping motivation on consumer impulsive buying

Methodology

The population of this research is all consumers who shopped at supermarkets in Manado namely: Multimart Ranotana, Fiesta Sam Ratulangi, Golden Sam Ratulangi, Jumbo Sam Ratulangi, and Freshmart Bahu. As the population is large and cannot be known with certainty, so the sampling was carried out by non-probability sampling method. The sample sizes of this study as many as 250 people in which each supermarket represent 50 participants. The sampling technique used convenience sampling or 
random sampling which is sampling where the selection of elements based on convenience samples or make investigators easy because of the data obtained quickly (Supranto \& Nandan, 2013).

This study used the analytical techniques of SEM (Structural Equation Modeling) with Lisrel Version 8.80 program. A complete modeling SEM consists of Measurement Model and Structural Model.

\section{Results \& Discussions}

Hybrid model (basic model) using Lisrel 8.70 program acquired two models, the standardized models and t-values models, as shown in Figure 1 and 2 below.

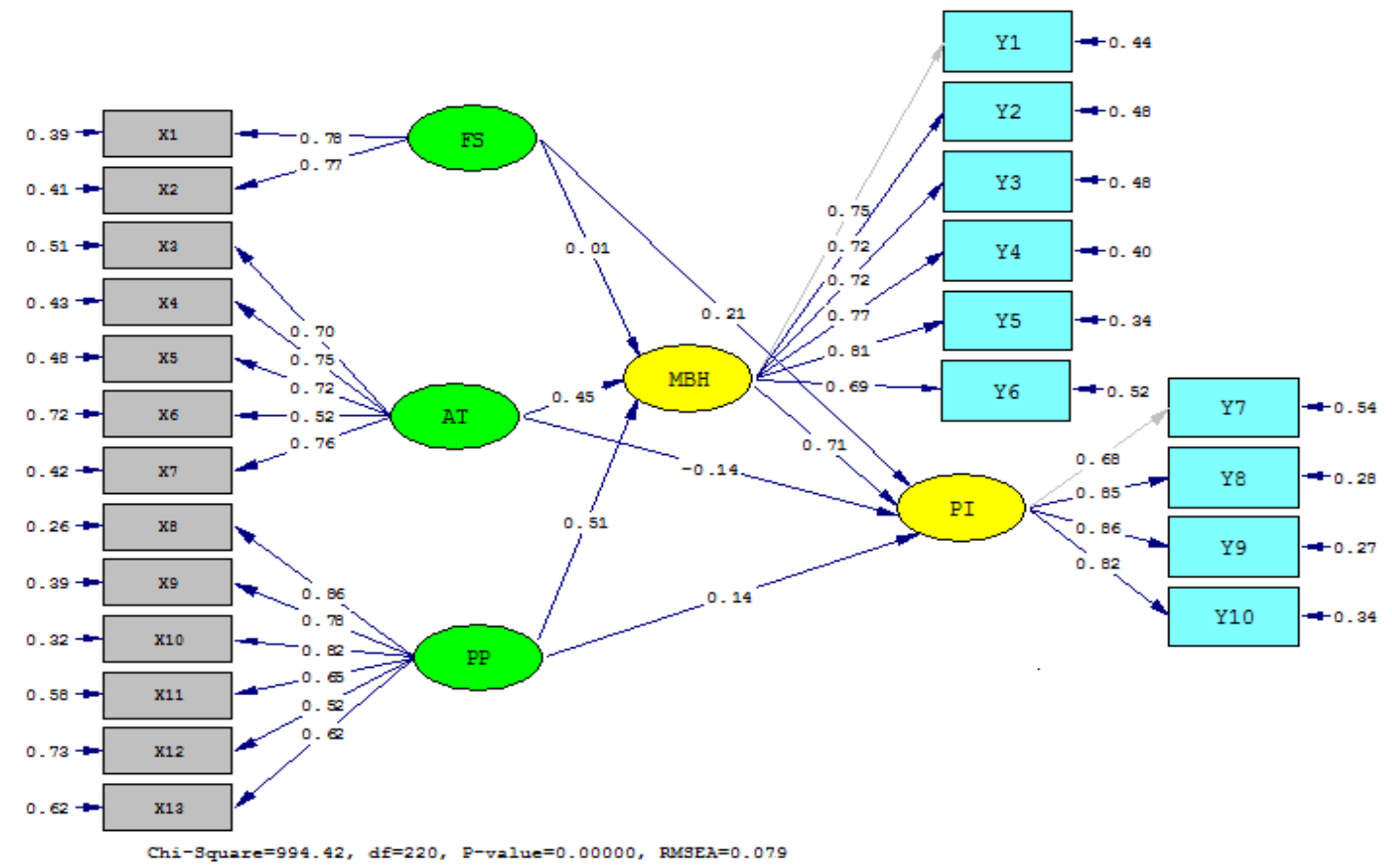

Figure 1. Standardized Hybrid Model

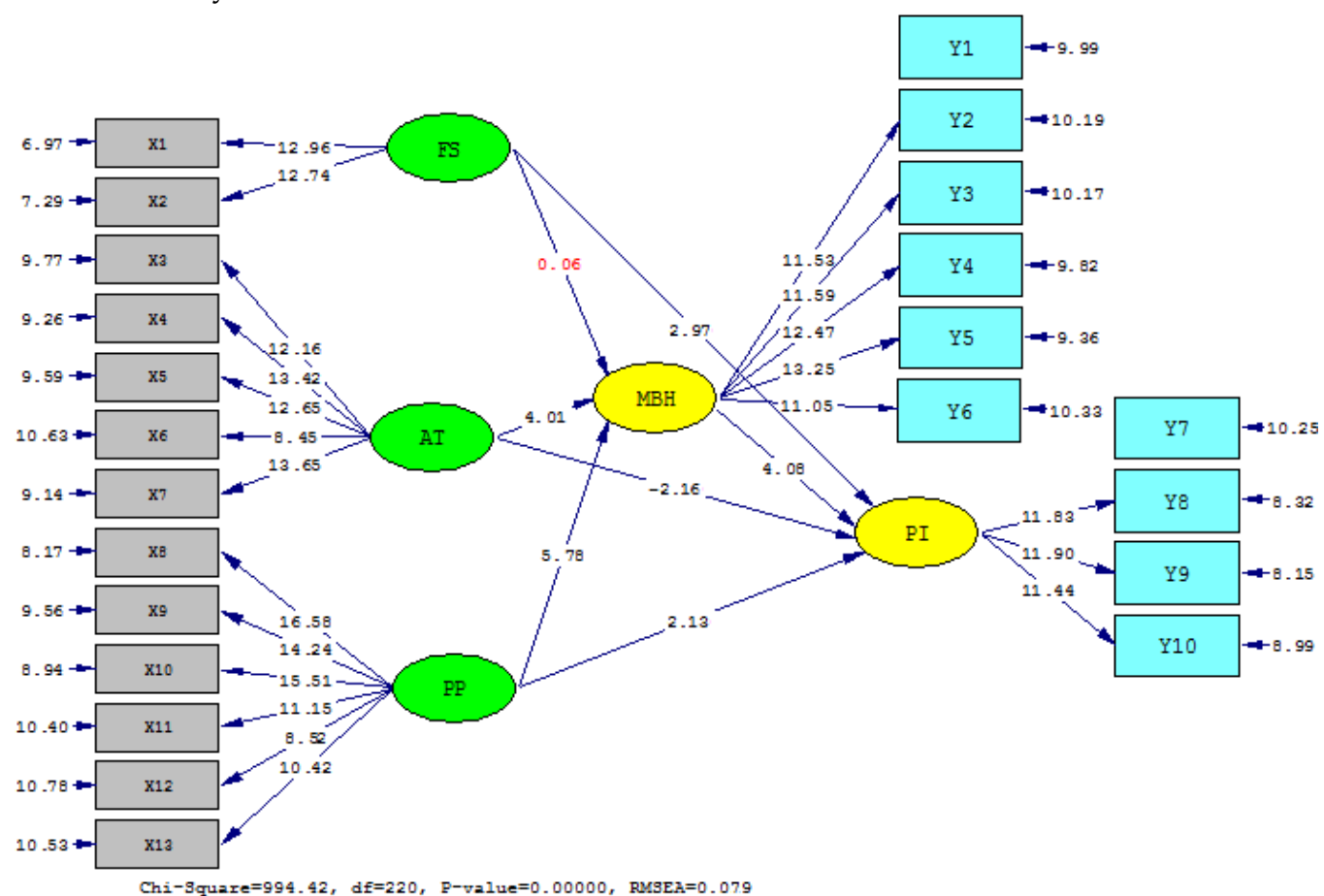

Figure 2. t-value Hybrid 
where: $\mathrm{FS}=$ Situational Factor, $\mathrm{AT}=$ Store Atmosphere, $\mathrm{PP}=$ Sales Promotion, $\mathrm{MBH}=$ Hedonic Shopping Motivation, PI=Impulsive Buying

Table 1. The Direct Effect of Situational Factor, Store Atmosphere, Sales Promotion on Hedonic Shopping Motivation and Impulsive Buying

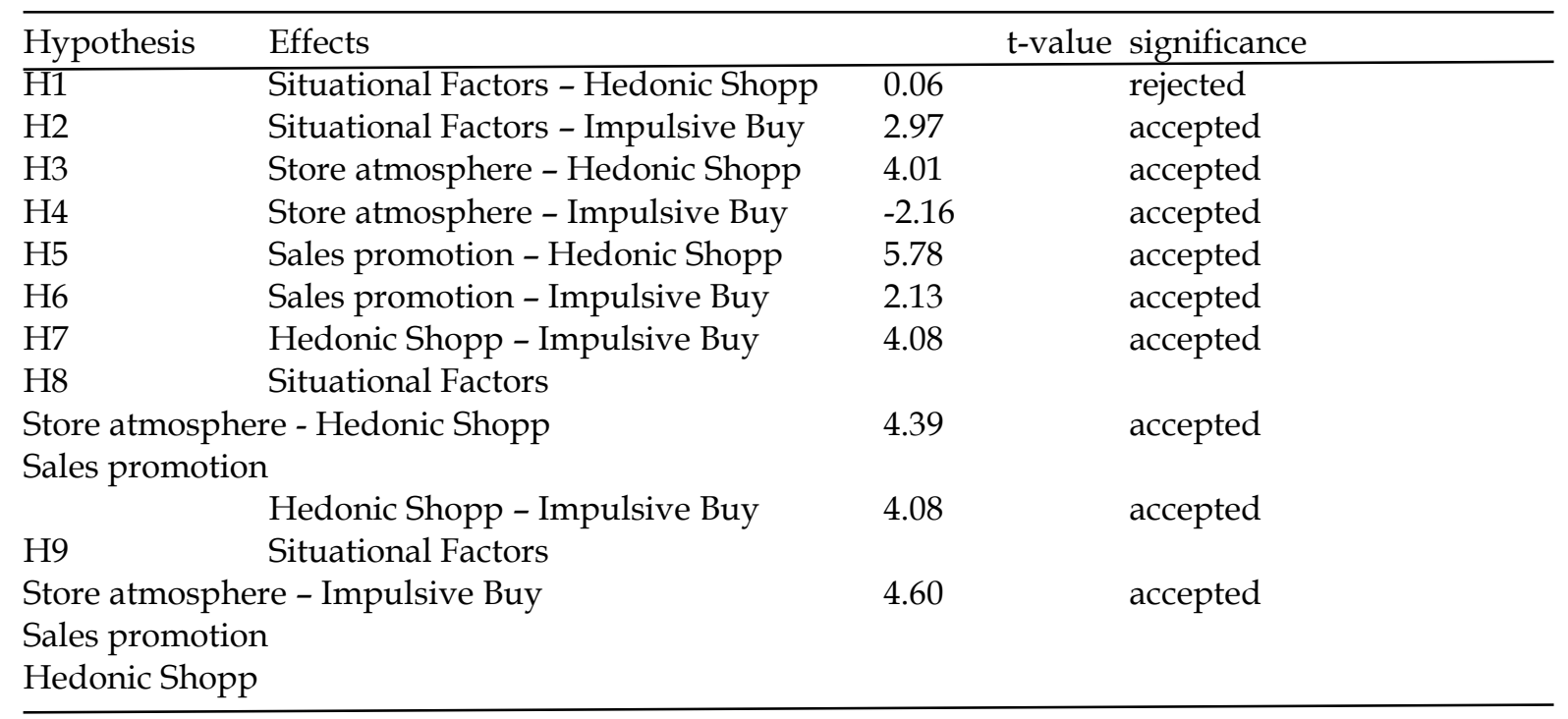

The Effect of Situational Factor, Store Atmosphere, and Sales Promotion on Hedonic Shopping Motivation. The measurement showed that hedonic shopping motivation is directly predicted by situational factors (0.0052); store atmosphere $(0,45)$; and sales promotions (0.51). Furthermore, those variables are contributed $84 \%$ to hedonic shopping motivation while the rest $16 \%$ is determined by other factors outside the study. Thus, the supermarket consumer hedonic shopping motivation is positively influenced by situational factors, store atmosphere, and sales promotion simultaneously.

The H1 testing showed that the $\mathrm{t}$-value of the effect of the situational factor on hedonic shopping motivation is $0.06<1.96$. Unfortunately, it can be said insignificant. Thus Hypothesis 1 is rejected. It means that although situational factors become better, it does not increase more hedonic shopping motivation. Consumers never see the situational factors as a reason to be hedonic. In other words, being hedonic is an internal issue rather than an external impression.

The $\mathrm{H} 3$ testing to assess the effect of store atmosphere on hedonic shopping motivation showed $\mathrm{t}$ value 4.01> 1.96. It means store atmosphere influences hedonic shopping motivation significantly. Hence, Hypothesis 3 is accepted. Supermarket needs to provide an attractive store atmosphere in order to increase consumers' hedonic shopping motivation. Both external and internal display should boost consumer's attention.

Likewise, the $t$-value for the effect of sales promotions on hedonic shopping motivation is 5.78> 1.96, which means a positive and significant relationship. Therefore, Hypothesis 5 is accepted. Thus, supermarket has to offer various attractive sales promotion such as a lower price, better value, or premiums or a combination of them to attract potential buyers who by emotionally. The more attractive sales promotions, the higher the hedonic shopping motivation will emerge.

Simultaneously can be seen from the F value in Figure 2 is $4.39>3.84$, so that situational factors, store atmosphere, and sales promotion simultaneously significantly effect on hedonic shopping motivation, means the better situational factors, the more attractive the store atmosphere, and the more attractive sales promotions, then the value of hedonic shopping motivation is higher. Thus Hypothesis 7 is accepted. The Effect of Situational Factor, Store Atmosphere, Sales Promotion, and Hedonic Shopping Motivation on Impulsive Buying. The results demonstrated that impulsive buying is predicted by hedonic shopping motivation (0.71); situational factor (0.21); store atmosphere (-0.14); and sales promotions variables (0.14). Moreover, all those variables are contributed $76 \%$ while the remain $24 \%$ is contributed by 
other factors. Thus, the supermarket consumer impulsive buying is influenced by situational factors, store atmosphere, sales promotion, and hedonic shopping motivation simultaneously.

Based on $t$-value from the effect of situational factors on impulsive buying is $2.97>1.96$, so it can be said to be significant. Thus, Hypothesis 2 is accepted. It means the better situational factors, the more impulsive buying increase. A supermarket that guarantees the availability of time and money will drive consumers' impulsive buying behaviour. Therefore, they can arrange the building in strata title organization and provide ATM in strategic locations to facilitate consumers.

Surprisingly, the relation of store atmosphere on impulsive buying is negative significant whereas -2.16> 1.96. Thus Hypothesis 4 is accepted. It means that the more attractive store atmosphere, then impulsive buying will be decreased. Further arguments in this case show that consumers feel disappointed in the research object. Bad layouts, small parking lots, unattractive building exterior, and narrow corridor between displays, it makes more chaotic than comfort. Supermarket managers need to address all these problems to make sure consumers impulsive buying emerges. If they cannot solve the problem, then consumers will switch to other places consider the municipal also have hypermarkets such as Hypermart, Giant, and Transmart Carrefour.

The relation of sales promotions on impulsive buying show t-value $2.13>1.96$, it is positive and significant Thus Hypothesis 6 is accepted. It means the more attractive sales promotions; the more impulsive buying will emerge. Therefore, supermarket needs to attract consumers through various sales promotion like free samples, coupons, gift, or a combination of all to enhance customers' impulsive behaviour.

The effect of hedonic shopping motivation on impulsive buying is 4.08> 1.96. Thus, hedonic shopping motivation is significantly affected by impulsive buying, which is means Hypothesis 8 is accepted. Further explanation is consumers who have hedonic value are easier to spend money rather than utilitarian consumers. Hedonic consumers never have seen money and time as barriers. They have pride and resources to do so. If they are motivated precisely, being impulsive is only a matter of time. Hence, managers need to provide unrefuted motivation to boost their impulsive tendency.

Simultaneously can be seen from F values at Figure 2 in the amount of 4.60> 3.84, so the situational factors, store atmosphere, sales promotion, and hedonic shopping motivation simultaneously significantly effect on impulsive buying, means the better situational factors, the more attractive the store atmosphere, the more attractive sales promotions, and the higher the hedonic shopping motivation, then the value of impulsive buying will increase. Thus Hypothesis 9 is accepted.

\section{Conclusion}

All hypotheses are accepted but H1, which is the measurement of the relation of situational factors to hedonic shopping motivation show the opposite way. Therefore, managers need to address to solve the problem of how hedonic behaviour can be obtained from situational factors. Interestingly, the measurement of $\mathrm{H} 4$, in assessing the relationship between store atmosphere and impulsive buying indicate negative and significant direction. Thus, managers have to assurance that they will provide a comfortable and enjoyable supermarket. If they fail, then the possibility of switching behaviour may occur.

The results also suggest a provider needs to improve every aspect of the research object. Situational factors include the availability of money and act as the leading factor. A pleasurable and cosy store atmosphere to avoid reducing in consumer impulsive buying. Sales promotion including, coupons, packaging price, premium prizes, free trial, and sample were provided as the primary factor.

The increasing of hedonic shopping motivation means an increase of hedonic shopping motivation for travel, for satisfaction, for a role, for a value, for social purposes, and for an idea, with the most dominant factor in shaping the hedonic shopping motivation is shopping for social purposes.

Simultaneously, the increase of the situational factor, store atmosphere, and sales promotion resulted in the increase of hedonic shopping motivation, with the most dominant factor in enhancing hedonic shopping motivation is sales promotion factor. Further, situational factor, store atmosphere, sales promotion, and hedonic shopping motivation simultaneously positive and significant effect on supermarket consumer impulsive buying with the most dominant factor in increasing impulsive buying is hedonic shopping motivation factor. 


\section{Research limitations and further considerations}

The study provides another consideration regarding consumer behaviour on how situational factors, store atmosphere, and sales promotion play as antecedent for hedonic shopping motivation and impulsive buying behaviour. However, the study still lacks a complex decision.

Hence, in order to reach another level of study and comprehensive result, we suggest the future research to add other constructs that could complete the study such as physical environment (services cape), product gimmick, or loyalty program.

\section{References}

Ahmad, T. (2011). "The Impulse Buying Behaviour of Consumes for The FMCG Products in Jodhpur", Australian Journal of Basic and Applied Sciences, 5(11), 1704-1710.

Babin, B. J., \& Attaway, J. S. (2000). “Atmospheric Affect as a Tool for Creating Value and Gaining Share of Customer," Journal of Business Research, 49, 91-99.

Babin, B. J., Darden, W. R., \& Griffin, M. (1994). Work and/or Fun: Measuring Hedonic and Utilitarian Shopping Value. Journal of Consumer Research, 20(4), 644-656.

Ballantine, P. W., Jack, R., \& Parsons, A. G. (2010). “Atmospheric Cues and Their Effect on The Hedonic Retail Experience", International Journal of Retail and Distribution Management Vol. 38(8), 641-653.

Beatty, S. E., \& Ferrel, M. E. (1998). “Impulse Buying: Modeling Its Precursors”, Journal of Retailing 74(2), 169-191.

Bohl, P. (2012). The Effects of Store Atmosphere on Shopping Behaviour - A Literature Review. Corvinus Marketing Studies. 1.

Nagadeepa, C., Tamil Selvi, J., \& Pushpa A. (2015). “Impact of Sale Promotion Technıques on Consumers' Impulse Buyıng Behaviour towards Apparels at Bangalore", Asian Journal of Management Sciences \& Education, Vol. 4(1).

Coley, A., \& Burgess, B. (2003). "Gender Differences in Cognitive and Affective Impulse Buying", Journal of Fashion Marketing and Management Vol. 7(3), 282-295.

Crawford, G., \& Melewar, T. C. (2003). “The Importance Of Impulse Purchasing Behaviour In The International Airport Environment", Journal Of Consumer Behaviour. Vol. 3(1), 85-98.

Dhaundiyal, M. \& Coughlan, J. (2009). "The Effect of Hedonic Motivations, Socialibility and Shyness on The Impulsive Buying Tendencies of The Irish Consumer", Irish Academy of Management, Dublin.

Dittmar, H., Beattie, J., \& Friese, S. (1995). Gender Identity and Material Symbols: Objects and Decision Considerations in Impulse Purchases, Journal of Economic Psychology,16(3), 491-511.

Foroughi, A., Buang N. A., \& Sadeghi R.H.M. (2012). "Exploring the Influence of Situational Factors (Money \& Time Avialable) on Impulse Buying Behaviour Among Different Ethics", International Journal of Fundamental Psychology \& Social Sciences (IJFPSS), 2(2), 41-44.

Foroughi, A., Buang N.A., Senik, Z.C., \& Sadeghi R.H.M. (2013). “Impulse Buying Behaviour and Moderating Role of Gender among Iranian Shoppers", Journal of Basic and Applied Scientific Research, 3(4),760-769.

Graa, A., Dani-Elkebir, M., \& Bensaid, M. (2014). “The impact of Environmental Factors on Impulse Buying Behavior Using the Mehrabian and Russell's Framework", Leonardo Journal of Sciences, p. 101-114.

Gutierrez, B. P. B. (2004). "Determinants of Planned and Impulse Buying: The Case of the Philippines", Asia Pacific Management Review, 9(6), 1061-1078.

Harmancioglu, N., Finney, R. Z., \& Joseph, M. (2009). "Impulse Purchases of New Product: An Empirical Analysis", Journal of Product and Brand Management 18(1), 27-37.

Hausman, A. (2000). "A Multi Method Investigation of Consumer Motivations in Impulse Buying Behavior", Journal of Consumer Marketing, 17(5) 403-419.

Hawkins, D. I. \& Mothersbaugh, D.L. (2009). Consumer Behavior. Building Marketing Strategy. Eleventh Edition. New York: McGraw Hill Irwin.

Iyer Easwar, S. \& Sucheta, S. Ahlawat (1987), “Deviations from a Shopping Plan: When and Why Do Consumers Not Buy as Planned, "in Advances in Consumer Research, Vol. 15, ed. Michael J. Houston, Provo, UT.: Association for Consumer Research, 246-249.

Kacen, J. J., \& Lee, J. A. (2002), "The Influence of Culture on Consumer Impulsive Buying Behavior", Journal of Consumer Psychology, 12(2), 163-76.

Karbasivar, A., \& Yarahmadi, H. (2011). "Evaluating Effective Factors on Consumer Impulse Buying Behavior”, Asian Journal of Business Management Studies, 2(4), 174-181.

Kotler, P., \& Keller, K. L. (2009), Marketing Management. 13 ${ }^{\text {th }}$ Edition. New Jersey: Upper Saddle River.

Kotler, P., \& Armstrong, G. (2012). Principles of Marketing. 14th Edition. New Jersey: Prentice Hall.

Maymand, M. M \& Ahmadinejad, M. (2011). "Impulse Buying: The Role of Store Environmental Stimulation and Situational Factors (An Empirical Investigation)", African Journal of Business Management, 5(34), 13057-13065, 28 December. 
Mihić, I., Kursan. (2010). “Assessing the Situational Factors and Impulsive Buying Behaviour: Market Segmentation Approach", Management, 15(2), 47-66

Muruganantham, G., \& Ravi-Shankar B. (2012). “A Review of Impulse Buying Behaviour", International Journal of Marketing Studies, 5(3).

Park, J. \& Lennon, S. J. (2006). “Psychological and Environmental Antecedents of Impulse Buying Tendency in The Multichannel Shopping Context", Journal of Consumer Marketing, 23(2), 58-68.

Piron, F. (1991). "Defining Impulse Purchasing", Advances in Consumer Research, 18, 509-514

Rohman, F. (2009). “The Role of Hedonic Value of Consumption and Impulsive Reaction as Mediation of the Effect of Situational Factors on Impulsive Purchasing Decisions in Malang City Boutique [Peran Nilai Hedonik Konsumsi dan Reaksi Impulsif sebagai Mediasi Pengaruh Faktor Situasional terhadap Keputusan Pembelian Impulsif di Butik Kota Malang]", Jurnal Aplikasi Manajemen, 7(2), Mei.

Rook, D. W. (1987). "The Buying Impulse”, Journal of Consumer Research, 14(2), 189-197.

Rook, D. W., \& Gardner, M. P. (1993). "In the mood: impulse buying's affective antecedents", Research in consumer behavior, 6(7), 1-28.

Silvera, D. H., Lavack, A. M., \& Kropp, F. (2008). “Impulse Buying: The Role of Affect, Social Influence, and Subjective Wellbeing", Journal of Consumer Marketing, 25(1), 23-33.

Soars, B. (2009). "Driving Sales Through Shopper's Sense of Sound, Sight, Smell, and Touch", International Journal of Retail and Distribution Management, 37(3), 286-298.

Srivastava, S. \& Kumar, M. (2013). "Evaluating Effective Situational Factors on Consumer Impulse Buying", International Journal of Applied Research EStudies, 2(3) Mar, 353.

Supranto \& Limakrisna, N. (2013). Practical Guidelines for Scientific Research to Arrange Thesis, Thesis, and Dissertation [Petunjuk Praktis Penelitian Ilmiah Untuk Menyusun Skripsi, Tesis, dan Disertasi]. 3 ${ }^{\text {rd }}$ Ed. Jakarta: Mitra Wacana Media.

Sumarwan, Ujang. (2011). “Consumer Behavior: Theory and Its Application in Marketing [Perilaku Konsumen: Teori dan Penerapannya Dalam Pemasaran], Jakarta: Ghalia Indonesia.

Tendai, M., \& Crispen, C. (2009). “In-Store Shopping Environment and Impulsive Buying”, African Journal of Marketing Management, 1(4), 102-108.

Tinne, W. S. (2010). “Impulse Purchasing: A Literature Overview”. ASA University Review, Vol. 4 No. 2, JulyDecember.

Utami, Christina. W. (2010). "Retail Management, Strategy and Operational Implementation of Modern Retail Business in Indonesia [Manajemen Ritel, Strategi dan Implementasi Operasional Bisnis Ritel Modern Di Indonesia]", Jakarta: Salemba Empat.

Wood, M. (2005). Discretionary Unplanned Buying in Consumer Society, Journal of Consumer Behavior, 4(4): $268-281$.

Wu, W-C., \& Huan, T-C. (2010). “The Effect of Purchasing Situation and Conformity Behavior on Young Students' Impulse Buying", African Journal of Business Management, 4(16), 3530-3540.

Xu, Y., \& Huang, J-S. (2014). "Effects of Price Discounts and Bonus Packs on Online Impulse Buying”, Social Behavior and Personality, 42(8), 1293-1302.

Youn, S. \& Faber, R. J. (2000). "Impulse Buying: Its Relation to Personality Traits and Cues", Advances in Consumer Research, 27, 179-1.

Zhang, Y., Sirion, C. \& Combs, H. (2011). “The Influence of The Mall Environment on Shopper's Values and Consumer Behavior in China", ASBBS Annual Conference, 18(1), 214-224.

Zhou, L. \& Wong, A. (2003). "Consumer impulse buying and in-store stimuli in Chinese supermarkets", Journal of International Consumer Marketing, 16, 37-53. 